\title{
DELICTUAL LIABILITY FOR DAMAGE CAUSED BY FULLY AUTONOMOUS VEHICLES: THE ESTONIAN PERSPECTIVE
}

by

\author{
TAIVO LIIVAK*, JANNO LAHE*
}

Self-driving vehicles have become a reality. For instance, in the summer of 2017, self-driving buses carried passengers on a designated route in Estonia's capital Tallinn. Regrettably, traffic accidents involving self-driving vehicles have also become a reality. This article focuses on fully autonomous vehicles. The safe and responsible use of fully autonomous vehicles calls for appropriate rules and an appropriate allocation of liability. Above all, fully autonomous vehicles pose a challenge to the law of delict. The article seeks to establish, based on the example of Estonian law, whether the application of delictual liability is affected by the autonomy of a vehicle and, if so, whether related differences are significant, and whether the law of delict needs to be modified in the light thereof. The issues are discussed primarily in the context of Estonian law, but parallels with German law are drawn as well. The conclusions drawn are more or less universal and can be taken into account also in other jurisdictions besides Estonia. The article analyses liability for damage caused by fully autonomous vehicles under general delictual liability, strict liability and product liability.

\section{KEY WORDS}

Autonomous Vehicles, Delictual Liability, Product Liability, Self-driving Vehicles, Strict Liability

\footnotetext{
taivo.liivak@ut.ee, Ph.D. candidate, Tartu University Law School, Estonia.

janno.lahe@ut.ee, Professor of Law of Delict, Tartu University Law School, Estonia; Adviser to the Civil Chamber of the Supreme Court of Estonia.
} 


\section{INTRODUCTION}

In the summer of 2017, passengers in Estonia's capital Tallinn were carried by self-driving buses in the course of a month-long international pilot project. ${ }^{1}$ Although the buses rode along a short route separated from conventional traffic, the test period was a landmark for Estonia, indicating that autonomous vehicles are becoming a reality. ${ }^{2}$ Such vehicles are being developed by many established manufacturers as well as new market participants seeking to disrupt not only the transport sector, but also the ways in which vehicles are being manufactured. ${ }^{3}$

In technological terms, this article focuses on fully autonomous vehicles (autonome Fahrzeuge) $^{4}$ where all persons in the vehicle are merely passengers. Even though one of the main aims of developing fully autonomous vehicles is to improve road safety, traffic accidents involving fully autonomous vehicles cannot be precluded. On the one hand, the laws of physics simply do not allow for halting a vehicle in an instant. On the other hand, a fully autonomous vehicle may find itself in a so-called dilemma situation where it must "decide" which person to harm (for instance, whether to drive off the road and into a tree or hit a child who has run onto the road). ${ }^{5}$ This so-called decision depends, above all, on how the software of the vehicle has been programmed.

In order to ensure the safe and responsible use of fully autonomous vehicles, appropriate rules and appropriate allocation of liability is crucial. ${ }^{6}$ Vehicles driving in the autonomous mode and autonomous test vehicles

1 Government Office EU Secretariat. (2017) Driverless buses arrive in Tallinn. [press release] 14 July. Available from: https://www.eu2017.ee/news/press-releases/driverless-busesarrive-tallinn [Accessed 30 May 2018].

2 In July 2017, the term "self-driving delivery robot" was added the Estonian Traffic Act (TA). It means a partially or fully automated or remotely controlled vehicle which moves on wheels or another chassis that is in contact with the ground, which uses sensors, cameras or other equipment for obtaining information on the surrounding environment and, based on the obtained information, is able to move partially or fully without being controlled by a driver (TA $\S 2$ clause $68^{1}$ ). The user and the controlling of a self-driving delivery robot was also defined (TA $\S 2$ clauses $68^{2}-68^{3}$ ).

3 See, for example, Geistfeld, M. (2017) A Roadmap for Autonomous Vehicles: State Tort Liability, Automobile Insurance, and Federal Safety Regulation. California Law Review, 105(6), pp. 1615-1616.

4 For a brief overview of the levels of driving automation see Smith, B. W. (2013) SAE Levels of Driving Automation. [blog entry] 18 December. Available from: http://cyberlaw.stanford. $\mathrm{edu} / \mathrm{blog} / 2013 / 12 /$ sae-levels-driving-automation [Accessed 30 May 2018]; SAE International. (2014) J3016. Taxonomy and Definitions for Terms Related to On-Road Motor Vehicle Automated Driving Systems. Available from: https://web.archive.org/web/20170903105244/https://www. sae.org/misc/pdfs/automated_driving.pdf [Accessed 30 May 2018].

5 For further information on the dilemma situation see Weber, P. (2016) Dilemmasituationen beim autonomen Fahren. Neue Zeitschrift für Verkehrsrecht, (6), pp. 249-254. 
have already been involved in as well as caused numerous accidents, including those resulting in fatalities. ${ }^{7}$ However, these vehicles were merely semi-autonomous. ${ }^{8}$

When a traffic accident occurs, civil liability issues arise. This article analyses delictual liability that arises or may arise from damage caused by a fully autonomous vehicle. ${ }^{9}$ More specifically, the article seeks answers to the following questions: is the application of delictual liability affected by the fact of whether damage has been caused by a conventional motor vehicle or a fully autonomous vehicle; if so, are these differences significant; and does the law of delict need to be modified as a result thereof?

These issues are approached, above all, from the point of view of Estonian law of delict. At the same time, it is quite clear that analogous questions can be raised in many legal systems. In more important matters, comparisons are drawn with the legal rules, case-law and legal writings of the Federal Republic of Germany as a legal system which was the main role model for drafting Estonian civil law following the restoration of Estonia's independence in 1991. The law of delict provisions of the Estonian Law of Obligations Act (LOA) ${ }^{10}$ distinguish between general

6 Contissa, G. et al. (2013) Liability and automation: Issues and challenges for socio-technical systems. Journal of Aerospace Operations, (2), pp. 79-98. Available from: https://pure.tue.nl/ws /files/3915758/24573390365552.pdf [Accessed 30 May 2018].

7 See, for example, Marshall, A. and Davies, A. (2018) Waymo's Self-Driving Car Crash in Arizona Revives Tough Questions. [online] Wired. Available from: https:/www.wired.com/ story/waymo-crash-self-driving-google-arizona/ [Accessed 30 May 2018]; Hawkins, A. J. (2018) Uber 'Likely' not at Fault in Deadly Self-Driving Car Crash, Police Chief Says. [online] The Verge. Available from: https:/www.theverge.com/2018/3/20/17142672/uber-deadlyself-driving-car-crash-fault-police [Accessed 30 May 2018]; Weise, E. and Marsh, A. (2018) Video Shows Google Self-Driving Van Accident in Arizona. [online] USA Today, 5 May. Available from: https://eu.usatoday.com/story/tech/2018/05/04/google-self-driving-vaninvolved-crash-arizona-driver-injured/582446002/ [Accessed 30 May 2018]; Nicola, S., Behrmann, E. and Mawad, M. (2018) It's a Good Thing Europe's Autonomous Car Testing Is Slow. [online] Bloomberg. Available from: https://www.bloomberg.com/news/articles/201803-20/it-s-a-good-thing-europe-s-autonomous-car-testing-is-slow [Accessed 30 May 2018].

8 They all had a driver responsible for actively overseeing the behaviour of the vehicle and taking over control. Because of problems with semi-autonomous driving, manufacturers such as, for instance, Ford and Google have decided to skip semi-autonomous driving altogether and aim straight for the highest level of autonomy. See Naughton, K. (2017) Ford's Dozing Engineers Side with Google in Full Autonomy Push. [online] Bloomberg. Available from: https://www.bloomberg.com/news/articles/2017-02-17/ford-s-dozingengineers-side-with-google-in-full-autonomy-push [Accessed 30 May 2018].

9 Of course, there may be a contract between the injured person and the person operating a fully autonomous vehicle under which damage is suffered (e.g. contract for carriage of passengers). Where damage has been caused by a breach of a contractual obligation, the claim for damages (under Estonian law) must usually be filed on the basis of provisions of contractual liability.

10 Law of Obligations Act (võlaõigusseadus) 2001. SI 2001/81, 487. Estonia: Riigi Teataja (State Gazette). In Estonian. English translation available from: https://www.riigiteataja.ee/en/eli/ 510012018003/consolide [Accessed 30 May 2018]. 
fault-based delictual liability ( $\S \S 1043-1055)$, strict liability ( $\S \S 1056-1060$ ) and liability for a defective product ( $\$ \S 1061-1067)$. This distinction largely determines the structure of this article. The possibility to bring a claim for damages based on the provisions of strict liability or product liability does not restrict the right of the injured person (also called a victim, aggrieved person/party) to file a claim based on provisions governing general delictual liability (LOA § 1056(3) and § 1061(5)).

Although damage caused by a fully autonomous vehicle can, in principle, be indemnified by a motor insurance undertaking, the article focuses on the law of delict. The reason lies in the fact that the basis for the insurer's indemnification obligation is, in turn, the liability of the injuring person (in common law, tortfeasor). Therefore, the motor insurance undertaking of the injuring person is required to indemnify damage only where the injuring person (insured person) is liable for it and, in principle, solely to the extent the injuring person is liable towards the injured person. ${ }^{11}$

\section{FULLY AUTONOMOUS VEHICLE AS AN INTELLIGENT MACHINE}

A system is autonomous to the extent that its behaviour is determined by its own experiences. ${ }^{12}$ Intelligence can be described as a way of coping with complexity and uncertainty owing to the ability to be aware of what is happening in the surrounding environment. ${ }^{13}$ Thus, a fully autonomous vehicle can be considered an intelligent machine. For the purposes of this article, a fully autonomous vehicle means a whole, i.e. a combination of hardware and software. Thereby the article does not focus on how the vehicle's full autonomy is attained in technical terms, be it based

${ }^{11}$ On the prerequisites for and scope of the liability of an insurer see Lahe, J. (2017) Estland. In: Bachmeier, W. (ed.) Regulierung von Auslandsunfällen. $2^{\text {nd }}$ edition. Baden-Baden: Nomos Verlagsgesellschaft, pp. 233-235; Lahe, J., Luik, O.-J. and Merila, M. (2017) Liikluskindlustuse seadus. Kommenteeritud väljaanne. Tallinn: Juura, pp. 98-100.

${ }_{12}$ Russell, S. J. and Norvig, P. (1995) Artificial Intelligence: A modern approach. New Jersey: Prentice Hall, p. 35.

13 See, for instance, Sterling, L. and Taveter, K. (2009) The Art of Agent-Oriented Modeling. Cambridge: The MIT Press, p. 6. It should be added that artificial intelligence can be defined in various ways, but in essence, these definitions tend to refer to similar phenomena demonstrated by machines. Artificial intelligence can be divided into narrow artificial intelligence (surpasses humans only in specific tasks), artificial general intelligence (human-like abilities) and superintelligence (beyond human abilities). See Russell, S. J. and Norvig, P. (1995) op. cit., pp. 2, 23-28; see also Dickson, B. (2017) What is Narrow, General and Super Artificial Intelligence. [online] Tech Talks. Available from: https://bdtechtalks.com/2017/05/12 /what-is-narrow-general-and-super-artificial-intelligence/[Accessed 30 May 2018]. 
on certain predefined criteria which make it capable of "thinking and deciding", on a comprehensive code doing exactly what it is supposed to do, or on some other solution. By and large, it is not of decisive importance from the aspect of delictual liability.

Considerable advancements have been made in the field of expert systems, which are limited to specific areas of application, including fully autonomous vehicles, which increase the ability of road users to cope with the complexity of traffic. Traffic accidents occur largely due to reasons attributable to humans who fail to cope with such complexity. Fully autonomous vehicles are seen by many as a way to "tame" the complexity of road use and reduce the number of accidents as well as open access to transportation for people who are currently often left out (e.g. the elderly, people with disabilities, etc.). ${ }^{14}$

The six levels of driving automation suggested by a global association of engineers span from no automation to full automation. ${ }^{15}$ Full automation means that at all times the automated driving system performs all aspects of the dynamic driving task under all roadway and environmental conditions that can be managed by a human driver. ${ }^{16}$ Some argue that, given the ability of fully autonomous machines to make highly consequential decisions in situations that may not be anticipated by their creators, society will need to consider whether existing liability rules will be up to the task of assigning responsibility for the acts they commit. ${ }^{17}$

14 As intelligent machines become more sophisticated in their ability to solve problems, a host of issues arise concerning the moral responsibilities for the acts of intelligent machines sophisticated enough to raise the possibility that they are moral agents and hence morally accountable for their acts (see Himma, K. E. (2009) Artificial Agency, Consciousness, and the Criteria for Moral Agency: What Properties Must an Artificial Agent Have to Be a Moral Agent? Ethics and Information Technology, 11(1), pp. 19-29. Available from: https://doi.org/10 $.1007 / \mathrm{s} 10676-008-9167-5$ [Accessed 30 May 2018]. Some even wonder whether intelligent machines should be granted personhood of sorts or be recognised as special-purpose animals or people (see Chopra, S. and White, L. F. (2011) A Legal Theory for Autonomous Artificial Agents. The University of Michigan Press., p. 153; Calo, R. (2015) Robotics and Lessons of Cyberlaw, California Law Review, 103(3), p. 549.

15 These levels are not normative, but technical. The elements indicate minimum rather than maximum system capabilities for each level. A particular vehicle may have multiple driving automation features. SAE International. (2014) J3016. Taxonomy and Definitions for Terms Related to On-Road Motor Vehicle Automated Driving Systems. Available from: https://web. archive.org/web/20170903105244/https://www.sae.org/misc/pdfs/automated_driving.pdf [Accessed 30 May 2018].

16 Ibid.

17 Vladeck, D. C. (2014) Machines without Principals: Liability Rules and Artificial Intelligence. Washington Law Review, 89 (1), pp. 117-150. Available from: http://digital.law. washington.edu/dspace-law/bitstream/handle/1773.1/1322/89WLR0117.pdf?sequence=1 [Accessed 30 May 2018]. 


\section{GENERAL DELICTUAL LIABILITY FOR DAMAGE CAUSED BY FULLY AUTONOMOUS VEHICLES}

Under $\S 1043$ of the $\mathrm{LOA}^{18}$, a person who unlawfully causes damage to another must compensate for the damage where the person who caused damage is at fault thereof or bears statutory liability for causing the damage. General delictual liability in Estonia is, similarly to general delictual liability under the German Civil Code (BGB) ${ }^{19}$ built in three stages. As a general rule, objective elements (objektiver Tatbestand) are verified at the first stage: the act of the person who causes damage, damage to the rights of the injured person, and a causal link between them. The second stage views unlawfulness and the third one is the fault of the injuring person.

In the event of damage caused by a fully autonomous vehicle, engaging in traffic may be deemed to be the act of the injuring person. The injured person's legal right that is being violated can, above all, be their life (LOA $\S 1045(1)$ clause 1), health (LOA $\S 1045(1)$ clause 2 ) or property (LOA $\S 1045(1)$ clause 5). The same applies to damage caused by a conventional motor vehicle. Likewise, establishing a causal link between the act of the injuring person and the damage suffered by the injured person is not special in any way. ${ }^{20}$

At the second stage of the criteria for general delictual liability, the unlawfulness of causing damage is established. Clauses 1-4 of LOA $\S 1045(2)$ establish the circumstances that preclude the unlawfulness of causing damage (e.g. consent or self-defence). Where damage is caused by the driver of a conventional motor vehicle, the unlawfulness can alternatively arise from a violation of a protective provision (LOA $\S 1045(1)$ clause 7 in combination with a protective provision in the $\mathrm{TA}^{21}$ ) or be based on the general catalogue of causing unlawful damage (LOA § 1045(1) clause

18 Law of Obligations Act (võlaõigusseadus) 2001. SI 2001/81, 487. Estonia: Riigi Teataja (State Gazette). In Estonian. English translation available from: https:/www.riigiteataja.ee/en/eli/ 510012018003/consolide [Accessed 30 May 2018].

19 Bamberger, H. G. et al. Beck'scher Online-Kommentar zum BGB. [online] $45^{\text {th }}$ edition, § 823, Rn. 15-41. Available from: https://beck-online-beck-de.ezproxy.utlib.ut.ee/?vpath=bibdata $\% 2$ fkomm $\% 2$ fBeckOKBGB_45\%2fBGB $\% 2$ fcont $\% 2$ fBECKOKBGB $\% 2$ eBGB $\% 2$ eP823\%2eglI $\% 2$ eg13\%2ehtm [Accessed 30 May 2018].

20 According to the Estonian legal approach, a causal link is established in two stages. First, the natural cause for damage is assessed (the conditio sine qua non test). Next, an assessment of the legal cause for the damage is made by asking whether the purpose of the breached rule was to obligate the injuring person and safeguard the injured person for the specific kind of damage (LOA § 127(2)). See alsoTampuu, T. (2017) Lepinguvälised võlasuhted (Non-contractual obligations). Tallinn: Juura, p. 213. 
2 - causing a bodily injury or health damage to the injured person; § 1045(1) clause 5 - infringement of ownership).

In the event of infringement of absolute legal rights such as human life, health or ownership, unlawfulness is based on the harmful effect as such, while it is not important whether the injuring person also violated any obligation. Unlawfulness comes from the wrongfulness of the outcome (Erfolgsunrecht).

Establishing unlawfulness merely based on the harmful effect is, however, not an exceptionless rule even in the event of infringing the absolutely protected legal rights. Where an absolutely protected right has been infringed by failure to act or where the harmful effect is a more remote outcome of the conduct of the injuring person, a duty which the latter has breached (Handlungsunrecht) must be identified. It may be a statutory duty or the general duty to maintain safety (generale Verkehrssicherungspflicht). ${ }^{22}$

While in the event of damage caused by a conventional motor vehicle the unlawfulness of causing damage can usually be derived from harming the injured person's legal right (or, alternatively, also from a violation of the provisions of the TA), it is rather questionable in the event of damage caused by a fully autonomous vehicle. One might argue that, for instance, in a situation where a person is inside a fully autonomous vehicle that causes a traffic accident, the person has not harmed the injured person's legal right by their active conduct. In such an event, the damage caused by the person who was inside the vehicle cannot be deemed to be unlawful owing to the mere harming of the injured person's legal right. In order to hold the person inside the vehicle liable, a duty which the person has breached should be established. Presumably, it cannot be a statutory duty (e.g. under the TA). Thus, the liability of the liable person can be based, above all, on a breach of the general duty to maintain safety. According to Estonian case-law, the general duty to maintain safety and the element of fault are entwined. ${ }^{23}$ Thus, when examining if a person has breached

${ }^{21}$ Traffic Act (liiklusseadus) 2010. SI 2010/44, 261. Estonia: Riigi Teataja (State Gazette). In Estonian. English translation available from: https://www.riigiteataja.ee/en/eli/521122017 002/consolide [Accessed 30 May 2018].

22 According to Estonian case-law, the general duty to maintain safety means a person's duty to make every reasonable effort to ensure that other persons are not harmed as a result of the persons' actions (see Case no. 3-2-1-73-13 (2013) Supreme Court (Civil Chamber), 20 June 2013).

${ }^{23}$ Case no. 3-2-1-73-13 (2013) Supreme Court (Civil Chamber), 20 June 2013. 
the general duty to maintain safety, one must substantively assess whether the person has been externally (i.e. objectively) negligent. ${ }^{24}$ It has been argued in the context of German law that putting "blind trust" in the autonomous vehicle technology over a long period may constitute a breach of the duty to maintain safety. ${ }^{25}$ Under Estonian law, one could partly agree with the opinion. The owner or possessor of a fully autonomous vehicle might be hypothetically criticised for a breach of the general duty to maintain safety where the vehicle is not properly serviced (e.g. software updates have not been made in a timely manner) or where detected errors are not reacted to "maintaining safety" should not usually require more of the owner or possessor.

The fault of the injuring person is the third main criterion of the general delictual liability. ${ }^{26}$ The types of fault are negligence, gross negligence and intent (LOA § 104(2)). Negligence is failure to exercise necessary care (LOA $\S 104(3))$. Gross negligence is failure to exercise necessary care to a material extent (LOA §104(4)). Intent is the will to bring about an unlawful consequence upon creation, performance or termination of an obligation (LOA §104(5)). In Estonian law of delict, the injured person's fault (incl. negligence) must also be assessed based on the characteristics of the injuring person. Under LOA $\S 1050$ (2), the situation, age, education, knowledge, abilities and other personal characteristics of a person must be taken into consideration upon assessment of the fault of the person. Under LOA $\S 1050(1)$, the negligence of the injuring person is presumed, i.e. the injuring person who wishes to avoid liability must prove the absence of their fault.

In the event of damage caused by a fully autonomous vehicle, the absence of fault (or a breach of the duty to maintain safety) may be the reason why general delictual liability is not applicable to the owner or possessor of the vehicle (or a person who simply travelled in the fully

24 The Supreme Court explained in its 20 June 2013 judgment in case no. 3-2-1-73-13 that since the general duty to maintain safety means, according to the generally recognised view, a duty of care for the purposes of the legal theory, negligence is one of the forms of fault under LOA § 104(2) and LOA § 1050(1) establishes that a person who unlawfully caused damage is presumed to be at fault, the defendant has the burden to prove that it did not breach the general duty to maintain safety.

25 Volker, M., Jänich, P. T. and Schrader, V. R. (2015) Rechtsprobleme des autonomen Fahrens. Neue Zeitschrift für Verkehrsrecht, 28(7), p. 316.

${ }^{26}$ For a comparative discussion on the fault of the injuring person see Lahe, J. (2013) The Concept of Fault of the Tortfeasor in Estonian Tort Law: A Comparative Perspective. Review of Central and East European Law, 38(2), pp. 141-170. 
autonomous vehicle at the time of the traffic accident). For instance, if a fully autonomous vehicle causes damage to a third party due to a bug in the control program, one cannot usually argue that the owner or possessor of the vehicle failed to exercise due care or perform the duty to maintain safety. As noted above, the situation may prove different where the vehicle has not been duly maintained or serviced. Nevertheless, it may be concluded that usually it is not reasonable or fruitful for the injured person who has suffered damage caused by a fully autonomous vehicle to bring a claim against the owner or possessor of the vehicle based on provisions governing general delictual liability.

In view of the above, it can be concluded that the injured person's ability to enforce their claim on the basis of general delictual liability is considerably affected by the fact of whether the damage was caused by a conventional motor vehicle or a fully autonomous vehicle. The difference will not create a deep practical issue where the injured person's chances of receiving compensation for damage are sufficiently ensured using other instruments, above all, legislation on strict liability and product liability.

\section{STRICT LIABILITY FOR DAMAGE CAUSED BY FULLY AUTONOMOUS VEHICLES}

Strict liability is liability for damage caused by a greater source of danger regardless of fault. In case of strict liability, attention is not paid to the act or fault of the injuring person, but it is examined if the harmful effect was caused by the manifestation of a higher risk characteristic of the thing or activity. Thus, being in control of the greater source of danger, the operator of a motor vehicle is liable for the damage caused regardless of whether the operator violated the TA while engaging in traffic or whether the operator was at fault. The causing of damage by a greater source of danger means the emergence of damage as a result of the manifestation of a heightened risk inherent in a thing or activity that constitutes the greater source of danger. ${ }^{27}$ As noted by H. Koziol, strict liability means liability for dangerousness. ${ }^{28}$ In Europe, the application of strict liability in case of damage caused by a motor vehicle is widespread.

27 See Case no. 3-2-1-161-10 (2011) Supreme Court (Civil Chamber), 2 March 2011.

28 Koziol, H. (2012) Basic Questions of Tort Law from a Germanic Perspective. Wien: Jan Sramek Verlag, p. 234. 
It has been argued that in countries where there is no strict liability, the same end result for the injured person is reached with the help of the insurance system or by raising the required standard of care. ${ }^{29}$

Where a motor vehicle causes damage, the easiest solution for the injured person is to build its claim for damages on LOA $\S 1057$, which states that the direct possessor of the motor vehicle is liable for any damage caused upon operating ${ }^{30}$ the motor vehicle. ${ }^{31}$ Under clause 40 of $\S 2$ of the TA, a power-driven vehicle means a vehicle that is powered by an engine, except for an engine-powered vehicle designated for use solely by a person with reduced mobility, an electric cycle, a self-balancing vehicle, a mini moped, a self-driving delivery robot, an off-road vehicle, a tram and a vehicle with a manufacturer speed of no more than six kilometres per hour. It should be added that the definition of a motor vehicle used in LOA $\S 1057$ is broader than the definition of a power-driven vehicle used in the TA, because under the respective provision of the LOA, for instance, an aircraft is also deemed to be a motor vehicle. Thus, it is obvious that a fully autonomous vehicle can be considered a motor vehicle within the meaning of LOA $\S 1057$.

Under LOA $\S 1057$, only the direct possessor of a motor vehicle can be held liable. Under the Law of Property Act (LPA) ${ }^{32} \S 33(1)$, a possessor is a person who has actual control over a thing. The second subsection of the same section states that a person who possesses a thing under a commercial lease, residential lease, deposit, pledge or other similar relationship which grants the person the right to possess the thing of another person temporarily is the direct possessor, while the other person is the indirect possessor. According to the case-law of the Estonian Supreme

${ }^{29}$ von Bar, C. (2009) Principles of European Law: Non-Contractual Liability Arising out of Damage Caused to Another. Munich: Sellier European Law Publishers, p. 703.

30 Damage is caused upon operating a motor vehicle, above all, when it arises from the purposeful use of the motor vehicle as a motor vehicle in traffic. The slow movement of a vehicle or, in exceptional circumstances, the static status of a vehicle on the road may be considered operating the vehicle (see Case no. 3-2-1-7-13 (2013) Supreme Court (Civil Chamber), 19 March 2013).

31 In LOA $\S 1056(1)$, the application of strict liability is limited to cases where (in the given context, by operating a motor vehicle) the death of a person, a bodily injury or health damage has been caused or where a thing has been damaged. In German law, strict liability relating to a motor vehicle is not provided for in the BGB, but in $\S 7$ of the Strassenverkehrsgesetz (StVG), according to subsection 1 of which the liability of the keeper (Halter) of a motor vehicle is not dependent on fault. However, the liability of the driver is fault-based (StVG § 18(1)).

32 Law of Property Act (asjaõigusseadus). 1993. SI 1993/39, 590. Estonia: Riigi Teataja (State Gazette). In Estonian. English translation available from: https://www.riigiteataja.ee/en/eli/ 504012018002/consolide [Accessed 7 June 2018]. 
Court, the liability under LOA $\S 1057$ rests with, above all, the person who has actual control over a motor vehicle regardless of the legal ground or absence thereof. In other words, with the person who controls the vehicle by deciding when and where it moves, bears the related costs and economic risks, and enjoys advantages arising from using the vehicle. ${ }^{33}$

The driver of a motor vehicle is not always deemed to be having actual control over the vehicle. The most common situation in that regard is the performance of employment duties using the employer's motor vehicle. Under LPA §33(3), a person who exercises actual control over a thing according to the orders of another person in the household or enterprise of the other person is not a possessor. Thus, in the given case LOA $\S 1057$ is not applicable to an employee either. ${ }^{34}$ At the same time, the servient possessor may still be liable under provisions governing fault-based delictual liability. As noted above, it would not be an effective option from the point of view of a person who has suffered damage caused by a fully autonomous vehicle, because usually delictual liability would be precluded due to the absence of fault or breach of the duty to maintain safety by the servient possessor. Thus, it may be concluded that, unlike with conventional vehicles, the liability of persons other than the direct possessors is considerably more limited in the event of damage caused by fully autonomous vehicles. It could also be argued that it is a reasonable solution, for an employee should not be held liable for causing damage with a fully autonomous vehicle in a situation where nothing is imputable to the employee regarding the damage caused.

The Estonian LOA also sets out general strict liability. ${ }^{35}$ It can be argued with high certainty that a fully autonomous vehicle should be considered a greater source of danger for the purposes of LOA § 1056(2) (at least until the time when technology allows for avoiding accidents entirely). Thus, it

33 Case no. 3-2-1-7-13 (2013) Supreme Court (Civil Chamber), 19 March 2013.

34 Varul, P. et al. (2009) Võlaõigusseadus III. Kommenteeritud väljaanne (Law of Obligations Act. Commented Edition. Vol. III). Tallinn: Juura, p. 696.

35 The first sentence of LOA $\S 1056(1)$ states: "where damage is caused as a result of a danger characteristic of an especially dangerous thing or activity, the person who controls the source of danger is liable for causing the damage regardless of the person's fault." Under LOA § 1056(2), a thing or activity is deemed to be a greater source of danger where, due to its nature or to the substances or means used in connection therewith, major or frequent damage may arise therefrom even where due diligence expected of a professional is exercised. Where liability for causing damage by means of a source of danger is prescribed by law, it is presumed that the thing or activity constitutes a greater source of danger regardless of the fault of the person who controlled it. It should be noted that there is no general clause on strict liability in Germany. A brief overview concerning discussions on a general clause of strict liability in European law of delict is given in Koziol, H. (2012), op. cit., pp. 236-238. 
cannot be precluded that the driver of a motor vehicle who does not qualify as the direct possessor of the vehicle under LOA $\S 1057$ can still be deemed to be in control of the greater source of danger for the purposes of LOA $\S 1056(1)$ (the owner of the vehicle who is not the direct possessor could likewise be considered to be in control of the greater source of dangersuch need may arise, for instance, in the event of the insolvency of the direct possessor). Even though this view has not yet been confirmed in Estonian case-law, there is substance for such a discussion owing to a decision of the Supreme Court. The court held that a person who is riding a horse but who is simultaneously not the keeper of the animal for the purposes of LOA $\S 1060$ may be deemed to be in control of a greater source of danger under LOA $\S 1056(1){ }^{36}$

The fact that the respective provision contains a list of events where the strict liability of the direct possessor of the motor vehicle does not apply can be seen as the main problem in connection with the application of LOA $\S 1057$. Under LOA $\S 1057$ clauses $1-5$, the provision does not apply where:

1) the damage is caused to a thing being transported by the motor vehicle and not being worn or carried by a person in the vehicle;

2) the damage is caused to a thing deposited with the possessor of the motor vehicle;

3) the damage is caused by force majeure or by an intentional act on the part of the injured person, unless the damage is caused upon operation of an aircraft; ${ }^{37}$

4) the injured person participates in the operation of the motor vehicle;

5) the injured person is carried without charge and outside the economic activities of the carrier.

36 Case no. 3-2-1-27-07 (2007) Supreme Court (Civil Chamber), 18 April 2007. The application of the general clause of strict liability (LOA $\S 1056$ ) may be precluded by the fact that the injured person was somehow related to the greater source of danger. In the same decision, the Supreme Court noted that persons who participate in controlling a greater source of danger, place a greater source of danger under their temporary control or receive gains from controlling a greater source of danger are not, given the principle of good faith, entitled to claim on the basis of provisions governing strict liability that the person controlling the greater source of danger compensate for damage caused to them by the greater source of danger.

37 The force majeure precluding the liability of the person controlling a greater source of danger may be an extraordinary natural phenomenon that assumes the position of the danger emanating from the greater source of danger and the impact of which the person controlling the greater source of danger or the injured person could not and did not have to take into account (Case no. 3-2-1-111-05 (2005) Supreme Court (Civil Chamber), 21 November 2005). 
As noted above, in the case of these preclusions it is possible, based on LOA §1056(3), to apply general delictual liability towards the direct possessor of the motor vehicle, but due to the absence of fault or a breach of the duty to maintain safety, it may prove ineffectual. Thus, at first glance, it may seem as a serious problem.

A closer look at the preclusions set out in LOA $\S 1057$ clauses 1-5 allows for drawing a conclusion that these are unlikely to cause major practical problems also in the context of fully autonomous vehicles. As regards clauses 1 and 2, the injured person should, as a rule, be able to claim damages under contract law. ${ }^{38}$ Where damage has been caused by an intentional act or force majeure (clause 3), the causal link between the manifestation of a risk inherent in a vehicle and the damage caused to the injured person is broken and the injured person should not be entitled to damages (we would reach the same result also upon application of general delictual liability towards the possessor of a conventional motor vehicle). Where the injured person participates in operating a motor vehicle (clause 4), they usually act on a contractual basis (travelling in a bus or taxi does not qualify as participating in operating a motor vehicle). Thus, claims for damages under contract law are possible.

Perhaps the most problematic one is the preclusion contained in clause 5 . If A (the owner of a fully autonomous vehicle) carries B (an acquaintance of theirs) free of charge and outside their economic activities and an accident occurs in which B is injured, the application of LOA $\S 1057$ to A is not possible and fault-based liability would probably be precluded by the absence of A's fault. In such a situation, there may but does not need to be a contract between $\mathrm{A}$ and $\mathrm{B}$. It is possible that $\mathrm{A}$ was benevolently intervening in another's affairs (negotiorum gestio; Geschäftsführung ohne Auftrag) when carrying B. In the event where the intervention is justified, the beneficiary can claim damages, but only where the intervener was negligent (LOA § 1022(1)). Thus, the ultimate outcome may be that B cannot claim damages from $A$ under any ground. Yet it can also be argued that this is a fair outcome, because B voluntarily accepted the respective risk. Besides, B will in any event retain the right to claim damages from the manufacturer of the fully autonomous vehicle.

38 It should be added that, according to the general rule, contractual liability is similarly to strict liability not dependent on fault. The debtor is discharged from liability if the debtor breached a duty or obligation due to force majeure (LOA § 103(2)). 
[Vol. 12:1

\section{PRODUCT LIABILITY FOR DAMAGE CAUSED BY FULLY AUTONOMOUS VEHICLES}

The issue of product liability is probably more burning regarding fully autonomous vehicles than conventional motor vehicles. In a situation where damage is caused by a fully autonomous vehicle, one can almost always raise the question of a defect of the fully autonomous vehicle. For instance, if the injured person demands that the direct possessor of the vehicle compensate for damage under LOA $\S 1057$, the issue of product liability can usually be raised. This entitles the direct possessor who has compensated the injured person for damage to file a recourse claim against the manufacturer (provided, of course, that the manufacturer is indeed liable) based on LOA $\S 137(2)$, which regulates mutual recourse claims of persons that are jointly and severally liable for causing damage.

In the LOA, the rules regulating product liability are set out in $\S \S 1061-1067 .^{39}$ Keeping in mind fully autonomous vehicles, the following can be pointed out as prerequisites for product liability:

1) a legal right of the injured person has been infringed (death, bodily injury or health damage; with certain reservations also infringement of ownership; ${ }^{40}$

2) a defective fully autonomous vehicle has been put into circulation as a product;

3) there is a causal link between the defect of the fully autonomous vehicle and the damage caused to the injured person; and

4) the absence of circumstances precluding product liability. ${ }^{41}$

Under LOA § 1063(1), any movable, including electricity and computer software, is deemed to be a product, even where the movable forms a part of another movable or has become part of an immovable. Thus, both

39 The rules are based on Council Directive 85/374/EEC of 25 July 1985 on the approximation of the laws, regulations and administrative provisions of the Member States concerning liability for defective products. Official Journal of the European Union (L 210) 7 August 1985. Available from: https://eur-lex.europa.eu/legal-content/EN/TXT/?uri=uriserv:OJ.L_.1985.210 .01.0029.01.ENG [Accessed 30 May 2018] and Directive 1999/34/EC of the European Parliament and of the Council of 10 May 1999 amending Council Directive 85/374/EEC on the approximation of the laws, regulations and administrative provisions of the Member States concerning liability for defective products. Official Journal of the European Union (L 141) 4 June 1999. Available from: https://eur-lex.europa.eu/legal-content/EN/TXT/uri=uri serv:OJ.L_.1999.141.01.0020.01.ENG [Accessed 30 May 2018]. Thus, the product liability legislation of the Member States of the EU is largely similar.

40 LOA $\S 1061(1)$ and (2).

$41 \quad$ LOA $\S 1064$. 
the fully autonomous vehicle as a whole as well as, for instance, a computer program that controls the vehicle can be considered a product. By the same token, both the person who manufactured the fully autonomous vehicle as a whole as well as a part of the product (e.g. a computer program) can be considered the manufacturer. ${ }^{42}$

Thus, provided that the prerequisites for liability are met, the injured person can, in principle, file a claim for damages against the person who manufactured the fully autonomous vehicle as well as the persons who made parts thereof. Regardless of the seat of the manufacturer, the injured person can also file a claim against the manufacturer based on the place where the damaging act was committed or the damaging event occurred or based on the place where the damage was suffered. ${ }^{43}$

However, product liability is not absolute. LOA $\S 1064(1)$ stipulates that the manufacturer is not liable for damage arising from a product where the manufacturer proves that:

1) the manufacturer has not placed the product on the market;

2) circumstances exist on the basis of which it can be presumed that the product did not have the damage-causing defect at the time the product was placed on the market by the manufacturer;

3) the manufacturer did not make the product for sale or for marketing in any other manner and did not manufacture or market it in the course of the manufacturer's economic or professional activities;

4) the defect was caused by compliance of the product with mandatory requirements in force at the time of placing the product on the market;

5) given the level of scientific and technical knowledge at the time of placing the product on the market, the defect could not be detected.

Additionally, the producer of a raw material or a part of a product is not liable for damage where the producer proves that the defect of the raw

${ }^{42}$ LOA $\S 1062(1)$ clause 1.

43 Section 94 of the Code of Civil Procedure (CCP) (tsiviilkohtumenetluse seadustik). 2005. SI 2005/26, 87. Estonia: Riigi Teataja (State Gazette). In Estonian. English translation available from: https://www.riigiteataja.ee/en/eli/506022018001/consolide [Accessed 7 June 2018]. In Estonia, injured parties do not usually bring claims against manufacturers. To date, the Supreme Court is yet to make its first decision based on product liability legislation. 
material or part was caused by the construction of the finished product or the instructions given by the manufacturer of the finished product (LOA $\S 1064(2))$.

Upon holding the manufacturer liable for damage caused by defects of a fully autonomous vehicle or parts thereof, the key question is, above all, how to apply LOA $\S 1064(1)$ clause 5. In other words, how extensive will be manufacturers' chances of proving that a defect of the product could not have been detected based on the scientific and technical level at the time. Too extensive application of this exception cannot be deemed reasonable regarding defects of fully autonomous vehicles, because otherwise the product liability legislation would largely lose its meaning in the context of new technologies.

Similarly to strict liability, the manufacturer can be held liable based on general delictual liability in situation where product liability is precluded (LOA § 1061(5)). Where product liability rules are not applicable, for instance, because of LOA $\S 1064(1)$ clause 5 , this fact allows the manufacturer to easily prove that it was not at fault regarding the damage and still be discharged from liability.

It can be argued that there are no differences of principle when it comes to the application of product liability provisions based on whether damage has been caused by a fully autonomous vehicle or a conventional motor vehicle. However, it cannot be precluded that in the case of fully autonomous vehicles the courts are more eager to apply the preclusion of liability arising from LOA $\S 1064(1)$ clause 5 in order not to impede technological development.

\section{DIVISION OF LIABILITY IN THE EVENT OF MUTUAL DAMAGE}

An important special problem in connection with fully autonomous vehicles may be the question of how to divide liability in a situation where a fully autonomous vehicle and a conventional motor vehicle have caused mutual damage. ${ }^{44}$ In Estonian law, there is no separate legal rule for division of liability in the event of mutual damage caused by motor

\footnotetext{
44 Where mutual damage has been caused by two fully autonomous vehicles, it should be possible to rely on the general rules applicable to situations involving mutual damage caused by two conventional motor vehicles.
} 
vehicles. ${ }^{45}$ However, the ultimate damages can be adjusted based on a general rule that regulates the reduction of damages (LOA $\S 139(1)$ ), which states that where damage is caused in part by circumstances dependent on the injured person or due to a risk borne by the injured person, the amount of damages is reduced to the extent that such circumstances or risk contributed to the damage. ${ }^{46}$

The LOA is based on the idea according to which persons who have caused mutual damage with motor vehicles are (above all, based on LOA $\S 1057)$ fully liable for causing damage to each other in the first step, but the damages payable by either one of them can be adjusted on the basis of LOA $\S 139(1)$, i.e. the damages payable can be reduced because of the share of the injured person in causing the damage. Under LOA $\S 139$, on the one hand, the circumstances arising from the motor vehicle operational risk and, on the other hand, circumstances characterising the behaviour of the drivers can be taken into account upon reducing the damages. ${ }^{47}$

The reason for taking into account the motor vehicle operational risk (Betriebsgefahr) lies in the understanding that once a person already engages in traffic using a motor vehicle (i.e. enters a dangerous situation), alone this fact is a sufficient ground for reducing the damages to a certain extent. In the framework of the operational risk, one can distinguish between the general operational risk and a special operational risk. The circumstances affecting the general operational risk include, for instance, the mass, dimensions, speed of movement, roadworthiness and safety equipment of the vehicle. Thus, the risk arising from a heavy truck may be considerably higher than the risk arising from a moped. A special operational risk means the objective nature and dangerousness of a specific

45 Unlike in, for example, German law where, under StVG § 17, the obligation of multiple keepers of motor vehicles to compensate for damage caused to a third party depends on the circumstances of the accident, above all, on which person mainly caused the damage. Under StVG §17(2), the principle set out in subsection 1 also applies upon division of mutual liability between keepers of motor vehicles where damage has been caused to a keeper of a motor vehicle involved in the accident. The respective provisions also apply where the damage has been mutually caused by a motor vehicle and a trailer, a motor vehicle and an animal, and a motor vehicle and a train (StVG § 17(4)).

46 Special problems arise where more than two motor vehicles have been involved in causing damage. On such a situation see Bachmeier, W. (2010) Verkehrszivilsachen. 2nd edition. München: C. H. Beck, pp. 72-77.

47 Case no. 3-2-1-7-13 (2013) Supreme Court (Civil Chamber), 19 March 2013. The same criteria are followed upon division of liability also in German law. See Säcker, F. J., Rixecker, R. and Oetker, H. (2012) Münchener Kommentar zum Bürgerlichen Gesetzbuch. Band 2. Schuldrecht. Allgemeiner Teil. $6^{\text {th }}$ edition. München: Verlag C. H. Beck, p. 528. 
manoeuvre. Thereafter, upon reducing the damages, it is important to also assess the behaviour of the persons who were involved in the accident, above all, whether they failed to exercise due care and disregarded the traffic rules. ${ }^{48}$

On the basis thereof, the extent of reduction of both parties' damages is established. ${ }^{49}$ If the share of one person was higher in causing the accident, it must be taken into account upon reducing the damages on the basis of LOA $\S 139(1) .^{50}$

According to the opinions established in Estonian case-law, the damages must be presumably reduced $50 \%$ in a situation where both drivers breached the requirements for safe road use established in the TA and their share in the traffic accident was, given their behaviour as well as the operational risks emanating from their vehicles, more or less equal. ${ }^{51}$ By way of exception, the damages can be reduced to the minimum or be precluded in a situation where it has been established that the accident was caused solely by a severe mistake of one person, as a result of which the other person who did not break the rules, could not reasonably avoid the accident. ${ }^{52}$ In certain events, the share of the drivers involved in a traffic accident may also remain unknown. $\S 139$ of the LOA is also applied where it is not proven that either person breached the traffic rules. In such an event, the basis for reducing the damages is the operating risks arising from the vehicles. ${ }^{53}$

48 Case no. 3-2-1-7-13 (2013) Supreme Court (Civil Chamber), 19 March 2013.

49 In German law, Haftungsquoten. For a detailed discussion of the case-law regarding liability quotas see Grüneberg, C. (2007) Haftungsquoten bei Verkehrsunfällen. Eine systematische Zusammenstellung veröffentlichter Entscheidungen nach dem StVG. 10 ${ }^{\text {th }}$ edition. München: Verlag C. H. Beck.

50 Case no. 3-2-1-64-15 (2015) Supreme Court (Civil Chamber), 26 November 2015.

51 In German case-law, liability is divided 50-50 in the case of an equal operational risk and fault. For further information see Grüneberg, C (2007), op. cit.

52 Case no. 3-2-1-64-15 (2015) Supreme Court (Civil Chamber), 26 November 2015. Likewise, according to German case-law a person is discharged from the obligation to compensate for damage in the case of an unpreventable event (unabwendbares Ereignis). See Hentschel, P. (2003) Strassenverkehrsrecht. Beck'sche Kurzkommentare. 37 $7^{\text {th }}$ edition. München: Verlag C. H. Beck, pp. 227-231. Where the fault of a person is the overwhelming reason for the accident, it may eliminate the operational risk emanating from the other person's vehicle (Säcker, F. J., Rixecker, R. and Oetker, H. (2012), op. cit., p. 562). In general, a road user can rely on the fact that the other road user does not intentionally commit a severe breach of the traffic rules (Ibid., p. 537).

53 Case no. 3-2-1-64-15 (2015) Supreme Court (Civil Chamber), 26 November 2015. According to the case-law established in Germany, the liability quota of either person is $50 \%$ in such case. See Greger, R. (2007) Haftungsrecht des Strassenverkehrs. 4th edition. Berlin: De Gruyter Recht, p. 619. 
In the case of fully autonomous vehicles, one must first decide how to assess the size of their operational risk. On the one hand, one could argue that the operational risk of fully autonomous vehicles should be higher than that of conventional vehicles, because they are merely controlled by a computer program and a human basically lacks the opportunity to "correct" the program's errors. On the other hand, it could be argued that the operational risk of a fully autonomous vehicle should be considered smaller, because such vehicles do not cause damage due to human error and refrain from causing damage in so far as possible according to the laws of physics. For instance, it may happen that upon manifestation of a risk the breaking distance of a fully autonomous vehicle is considerably shorter, because the program is able to initiate breaking with virtually no reaction time.

With fully autonomous vehicles it is not possible to take into account the driver's behaviour (whether the driver violated the traffic rules). Therefore, it seems that the operational risk of fully autonomous vehicles must be assessed based on rules different from those applicable to conventional motor vehicles. For example, while damages are usually reduced by approx. 20-30\% based on the operational risk, ${ }^{54}$ there will likely be a need to deviate from this principle regarding fully autonomous vehicles and deem the operational risk of a fully autonomous vehicle to be higher than usual. This question is important because the reduction of the damages of one party to an accident affects the reduction of the damages of the other party. Presumably the ultimate result must be damages that do not exceed $100 \%$ in total, i.e. if it has been identified that the damages of one party must be reduced to $40 \%$, those of the other must be reduced to $60 \%$ in general.

When a fully autonomous vehicle, due to a programming error or otherwise, causes damage to an injured person who did not breach the traffic rules or was not negligent, the injured person's damages could be reduced only to the extent of the operational risk arising from their vehicle (20\% for instance, and therefore, the damages of the owner of the fully autonomous vehicle should be reduced presumably $80 \%$ ). Where a fully autonomous vehicle has caused damage in a way that in the case of a conventional vehicle would mean a severe mistake of the driver

54 Säcker, F. J., Rixecker, R. and Oetker, H. (2012), op. cit., p. 562. 
(e.g. driving onto the intersection while the traffic lights prohibit it), the damages of the owner of the fully autonomous vehicle should be reduced to zero and the damages caused to the injured person should be compensated for in full. Thus, the operational risk of the fully autonomous vehicles should be considered $100 \%$ in such event. If the damages of the owner of the fully autonomous vehicle were reduced by merely 20-30\% in such an event, it would lead to a clearly unfair result for the other party involved in the traffic accident.

Finally, it may be argued that even though the fair division of liability in the event where damage is caused by a fully autonomous vehicle calls for certain adjustment of the practice of application of LOA $\S 139$, it is not a complicated task upon shaping case-law. At any rate, there are no rules in Estonian law, which would prevent the courts from reaching a fair and just result upon division of liability in the described situations.

\section{CONCLUSIONS}

Fully autonomous vehicles will be put into daily operation soon. This scenario must also be taken into account in legislative drafting and case-law. As noted in the introduction, traffic accidents caused by semi-autonomous vehicles have become a reality. Thereby the main question is whether traditional rules of the law of delict adequately regulate liability for damage caused by fully autonomous vehicles. This question will arise in all countries where fully autonomous vehicles are introduced.

It can be argued that the application of delictual liability is affected by the fact of whether damage is caused by a conventional motor vehicle or a fully autonomous vehicle. Above all, it is expressed in the impossibility to apply the general fault-based liability towards the owner or possessor of a fully autonomous vehicle. The reason lies in the fact that usually the owner of a fully autonomous vehicle cannot be reproached for negligence or a breach of the duty to maintain safety. The difficulty of applying fault-based liability upon damage caused by a fully autonomous vehicle is universal and should also concern other legal systems besides Estonia. However, there is no reason to consider this a serious problem in practice, provided that the injured person is guaranteed damages based on provisions governing strict liability.

An analysis of Estonian law of delict allows for drawing a conclusion that, in most cases, the injured person can file a claim under LOA 1057 
against the direct possessor of the fully autonomous vehicle, regardless of their fault. If the direct possessor proves insolvent, general strict liability might be of help, for it allows for holding, for instance, the owner of the fully autonomous vehicle who is simultaneously not the direct possessor of the vehicle liable as a person in control of a greater source of danger. The application of LOA $\S 1057$ is indeed restricted in the events specified in clauses 1-5, but these preclusions do not considerably affect the injured person's position. In the case of the preclusions, the injured person may have the right to claim damages under contract law (clauses 1, 2 and 4). In circumstances described in clause 3 of $\S 1057$ of the LOA (the injured person's intent or force majeure), the injured person is clearly not entitled to damages. It is debatable whether the preclusion contained in clause 5 of $\S 1057$ of the LOA (carrying the injured person free of charge and outside economic activities) is justified with regard to fully autonomous vehicles.

As for the application of provisions governing product liability, there are no fundamental differences based on whether damage arises from a defect of a fully autonomous or conventional motor vehicle. The fair and just division of liability for mutual damage caused by a fully autonomous vehicle and a conventional motor vehicle is possible without amending the law in force.

Thus, the Estonian example illustrates that the safeguarding of the rights of the injured person is not considerably influenced by whether the damage has been caused by a fully autonomous vehicle or a conventional motor vehicle. The traditional law of delict is largely able to safeguard the injured person regardless of the fact that fault-based liability cannot usually be applied regarding fully autonomous vehicles. However, the importance of product liability legislation may start to play a more important role in that regard. Therefore, there is no urgent need to amend the law of delict in the anticipation of fully autonomous vehicles. By and large, this conclusion should also apply to other countries where the structure of the law of delict resembles that of Estonia.

However, it cannot be precluded that in countries that have not introduced strict liability for damage caused by motor vehicles or where the preclusions of strict liability are considerable, the rules of the law of delict may need some modification. There would be no practical need for it in a situation where the insurance system guaranteed the injured person 
compensation also in a situation where the injuring person was not liable for the damage.

\section{LIST OF REFERENCES}

[1] Bachmeier, W. (2010) Verkehrszivilsachen. $2^{\text {nd }}$ edition. München: C. H. Beck.

[2] Bamberger, H. G. et al. Beck'scher Online-Kommentar zum BGB. [online] $45^{\text {th }}$ edition, $\S 823$, Rn. 15-41. Available from: https://beck-online-beck-de.ezproxy.utlib.ut.ee/?vpath=bib data $\% 2$ fkomm $\% 2$ fBeckOKBGB_45\%2fBGB $\% 2$ fcont $\% 2$ fBECKOKBGB $\% 2$ eBGB $\% 2$ eP823\%2 eglI\%2eg13\%2ehtm [Accessed 7 June 2018].

[3] Calo, R. (2015) Robotics and Lessons of Cyberlaw, California Law Review, 103(3), pp. 513-563.

[4] Case no. 3-2-1-111-05 (2005) Supreme Court (Civil Chamber), 21 November 2005.

[5] Case no. 3-2-1-27-07 (2007) Supreme Court (Civil Chamber), 18 April 2007.

[6] Case no. 3-2-1-161-10 (2011) Supreme Court (Civil Chamber), 2 March 2011.

[7] Case no. 3-2-1-7-13 (2013) Supreme Court (Civil Chamber), 19 March 2013.

[8] Case no. 3-2-1-73-13 (2013) Supreme Court (Civil Chamber), 20 June 2013.

[9] Case no. 3-2-1-64-15 (2015) Supreme Court (Civil Chamber), 26 November 2015.

[10] Chopra, S. and White, L. F. (2011) A Legal Theory for Autonomous Artificial Agents. The University of Michigan Press.

[11] Code of Civil Procedure (tsiviilkohtumenetluse seadustik) 2005. SI 2005/26, 87. Estonia: Riigi Teataja (State Gazette). In Estonian. English translation available from: https://www.riigiteataja.ee/en/eli/506022018001/consolide [Accessed 7 June 2018].

[12] Contissa, G. et al. (2013) Liability and automation: Issues and challenges for socio-technical systems. Journal of Aerospace Operations, (2), pp.79-98. Available from: https://pure.tue.nl/ws/files/3915758/24573390365552.pdf [Accessed 30 May 2018].

[13] Council Directive 85/374/EEC of 25 July 1985 on the approximation of the laws, regulations and administrative provisions of the Member States concerning liability for defective products. Official Journal of the European Union (L 210) 7 August 1985. Available from: https://eur-lex.europa.eu/legal-content/EN/TXT/uri=uriserv:OJ.L_.1985.210.01.0029. 01.ENG [Accessed 30 May 2018].

[14] Dickson, B. (2017) What is Narrow, General and Super Artificial Intelligence. [online] Tech Talks. Available from: https://bdtechtalks.com/2017/05/12/what-is-narrow-general-andsuper-artificial-intelligence/ [Accessed 30 May 2018]. 
[15] Directive 1999/34/EC of the European Parliament and of the Council of 10 May 1999 amending Council Directive 85/374/EEC on the approximation of the laws, regulations and administrative provisions of the Member States concerning liability for defective products. Official Journal of the European Union (L 141) 4 June 1999. Available from: https:/eur-lex.europa.eu/legal-content/EN/TXT/?uri=uriserv:OJ.L_.1999.141.01.0020.01. ENG [Accessed 30 May 2018].

[16] Geistfeld, M. (2017) A Roadmap for Autonomous Vehicles: State Tort Liability, Automobile Insurance, and Federal Safety Regulation. California Law Review, 105(6).

[17] Government Office EU Secretariat. (2017) Driverless buses arrive in Tallinn. [press release] 14 July. Available from: https://www.eu2017.ee/news/press-releases/driverless-busesarrive-tallinn [Accessed 30 May 2018].

[18] Greger, R. (2007) Haftungsrecht des Strassenverkehrs. 4th edition. Berlin: De Gruyter Recht.

[19] Grüneberg, C. (2007) Haftungsquoten bei Verkehrsunfällen. Eine systematische Zusammenstellung veröffentlichter Entscheidungen nach dem StVG. 10 ${ }^{\text {th }}$ edition. München: Verlag C. H. Beck.

[20] Hawkins, A. J. (2018) Uber 'Likely' not at Fault in Deadly Self-Driving Car Crash, Police Chief Says. [online] The Verge. Available from: https://www.theverge.com/2018/3/20/17142672/ uber-deadly-self-driving-car-crash-fault-police [Accessed 30 May 2018].

[21] Hentschel, P. (2003) Strassenverkehrsrecht. Beck'sche Kurzkommentare. $37^{\text {th }}$ edition. München: Verlag C. H. Beck.

[22] Himma, K. E. (2009) Artificial Agency, Consciousness, and the Criteria for Moral Agency: What Properties Must an Artificial Agent Have to Be a Moral Agent? Ethics and Information Technology, 11(1), pp. 19-29. Available from: https://doi.org/10.1007/s10676008-9167-5 [Accessed 30 May 2018].

[23] Koziol, H. (2012) Basic Questions of Tort Law from a Germanic Perspective. Wien: Jan Sramek Verlag.

[24] Lahe, J. (2013) The Concept of Fault of the Tortfeasor in Estonian Tort Law: A Comparative Perspective. Review of Central and East European Law, 38(2), pp. 141-170.

[25] Lahe, J. (2017) Estland. In: Bachmeier, W. (ed.) Regulierung von Auslandsunfällen. 2nd edition. Baden-Baden: Nomos Verlagsgesellschaft.

[26] Lahe, J., Luik, O.-J. and Merila, M. (2017) Liikluskindlustuse seadus. Kommenteeritud väljaanne. Tallinn: Juura. 
[27] Law of Obligations Act (võlaõigusseadus) 2001. SI 2001/81, 487. Estonia: Riigi Teataja (State Gazette). In Estonian. English translation available from: https://www.riigiteataja.ee/en/ eli/510012018003/consolide [Accessed 30 May 2018].

[28] Law of Property Act (asjaõigusseadus). 1993. SI 1993/39, 590. Estonia: Riigi Teataja (State Gazette). In Estonian. English translation available from: https://www.riigiteataja.ee/en/ eli/504012018002/consolide [Accessed 7 June 2018].

[29] Marshall, A. and Davies, A. (2018) Waymo's Self-Driving Car Crash in Arizona Revives Tough Questions. [online] Wired. Available from: https://www.wired.com/story/waymocrash-self-driving-google-arizona/ [Accessed 30 May 2018].

[30] Naughton, K. (2017) Ford's Dozing Engineers Side with Google in Full Autonomy Push. [online] Bloomberg. Available from: https://www.bloomberg.com/news/articles/2017-0217/ford-s-dozing-engineers-side-with-google-in-full-autonomy-push [Accessed 30 May 2018].

[31] Nicola, S., Behrmann, E. and Mawad, M. (2018) It's a Good Thing Europe's Autonomous Car Testing Is Slow. [online] Bloomberg. Available from: https://www.bloomberg.com/news/ articles/2018-03-20/it-s-a-good-thing-europe-s-autonomous-car-testing-is-slow [Accessed 30 May 2018].

[32] Säcker, F. J., Rixecker, R. and Oetker, H. (2012) Münchener Kommentar zum Bürgerlichen Gesetzbuch. Band 2. Schuldrecht. Allgemeiner Teil. $6^{\text {th }}$ edition. München: Verlag C. H. Beck.

[33] SAE International. (2014) J3016. Taxonomy and Definitions for Terms Related to On-Road Motor Vehicle Automated Driving Systems. Available from: https://web.archive.org/web/ 20170903105244/https://www.sae.org/misc/pdfs/automated_driving.pdf [Accessed 30 May 2018].

[34] Smith, B. W. (2013) SAE Levels of Driving Automation. [blog entry] 18 December. Available from: http://cyberlaw.stanford.edu/blog/2013/12/sae-levels-driving-automation [Accessed 30 May 2018].

[35] Sterling, L. and Taveter, K. (2009) The Art of Agent-Oriented Modeling. Cambridge: The MIT Press.

[36] Russell, S. J. and Norvig, P. (1995) Artificial Intelligence: A modern approach. New Jersey: Prentice Hall.

[37] Strassenverkehrsgesetz (StVG) (Road Traffic Act) 2003. SI 2003/310, 919. In German.

[38] Tampuu, T. (2017) Lepinguvälised võlasuhted (Non-contractual obligations). Tallinn: Juura. 
[39] Traffic Act (liiklusseadus) 2010. SI 2010/44, 261. Estonia: Riigi Teataja (State Gazette). In Estonian. English translation available from: https://www.riigiteataja.ee/en/eli/5211220 17002/consolide [Accessed 30 May 2018].

[40] Varul, P. et al. (2009) Võlaõigusseadus III. Kommenteeritud väljaanne (Law of Obligations Act. Commented Edition. Vol. III). Tallinn: Juura.

[41] Vladeck, D. C. (2014) Machines without Principals: Liability Rules and Artificial Intelligence. Washington Law Review, 89 (1), pp. 117-150. Available from: http://digital. law.washington.edu/dspace-law/bitstream/handle/1773.1/1322/89WLR0117.pdf? sequence $=1$ [Accessed 30 May 2018].

[42] Volker, M., Jänich, P. T. and Schrader, V. R. (2015) Rechtsprobleme des autonomen Fahrens. Neue Zeitschrift für Verkehrsrecht, 28(7), pp. 313-318.

[43] von Bar, C. (2009) Principles of European Law: Non-Contractual Liability Arising out of Damage Caused to Another. Munich: Sellier European Law Publishers.

[44] Weber, P. (2016) Dilemmasituationen beim autonomen Fahren. Neue Zeitschrift für Verkehrsrecht, (6), pp. 249-254.

[45] Weise, E. and Marsh, A. (2018) Video Shows Google Self-Driving Van Accident in Arizona. [online] USA Today, 5 May. Available from: https://eu.usatoday.com/story/tech/2018/05/ 04/google-self-driving-van-involved-crash-arizona-driver-injured/582446002/ [Accessed 30 May 2018]. 